\title{
Effect of pot marigold (Calendula officinalis L.) and cypress spurge (Euphorbia cyparissias L.) plant water extracts on the occurrence of pest insects on white cabbage
}

\author{
Beata Jankowska, Anna Wilk \\ Department of Plant Protection \\ Faculty of Horticulture, University of Agriculture in Krakow \\ 29 Listopada 54, 31-425 Kraków, Poland \\ e-mail: jankowskab@ogr.ar.krakow.pl
}

\begin{abstract}
In 2007-2008 the effects of pot marigold (Calendula officinalis L.) and cypress spurge (Euphorbia cyparissias L.) water extracts on the occurrence of pest insects on white cabbage were tested. The numbers of cabbage aphid (Brevicoryne brassicae L.) were significantly lower on the treated plants. During the period of the most numerous occurrence of aphids on the unsprayed plants, their number was almost twice as high as on the plants sprayed with spurge extract and almost three times as high as on the plants sprayed with marigold extracts. Spraying plants had an effect on the number of Phyllotreta atra and P. nemorum beetles and Pieris rapae L. eggs. Pot marigold extract proved to be the most effective in this respect. Egg clusters of large white butterfly (P. brassicae L.) and cabbage moth (Mamestra brassicae L.) were observed only in 2008, and only on the control. In the case of the diamondback moth, Plutella xylostella L., only marigold extract had a positive impact on reducing its number. Diamondback moth larvae numbers were even slightly higher on plants treated with cypress spurge extract than on the control plots where plants had not been sprayed.
\end{abstract}

Key words: Brevicoryne brassicae L., lepidoptera cabbage pests, Phyllotreta, plant extracts

\section{INTRODUCTION}

Among the numerous phytophagous insects occurring on different botanical varieties of cabbage including white cabbage, the most important were cabbage aphid Brevicoryne brassicae L. (Jankowska and Wiech 2004), several lepidoptera pests (Jankowska 2005, 2006) and others (Szwejda 2004). Each of these pests has the potential of reducing the marketable yield severely or completely destroying the crop. The misuse and excessive use of chemical pesticides causes irrevocable changes in biocenosis and has a negative influence on the quality of agricultural products. In recent years, interest in the possibilities of the application of natural substances as plant protection against pests has been growing. Botanical insecticides are generally pest-specific and are relatively harmless to non-target organisms, including humans. They are safer as well as environmentally friendlier than synthetic insecticides. Plants may be an alternative to the currently used insect control agents because they virtually are a rich source of bioactive organic chemicals. They contain a number of compounds (usually secondary substances) that have a repulsive effect on insects by acting as repellents, antifeedants, and toxins, and have an antibacterial and fungistatic impact (Nawrot 1984, Burgieł 2005).

The aim of the research was to assess the influence of water extracts from pot marigold (Calendula officinalis L.) and cypress spurge (Euphorbia cyparissias L.) on the settling of pest insects on white cabbage. 


\section{MATERIAL AND METHODS}

The research was carried out in 2007-2008 at a farm at Tropiszowo (2007) and the experimental station of the Plant Protection Department in Mydlniki near Kraków (2008). Middle-early season 'Tucana $\mathrm{F}_{1}$ ' white cabbage was used in the experiment. Seedlings were transplanted in the first ten days of June on 12 plots (four plot repetition for each combination). On each plot there were 40 plants transplanted at a $40 \times 50 \mathrm{~cm}$ spacing. A randomised block design was used. To prepare extracts from pot marigold (from the researcher's own cultivation) and cypress spurge (from its natural habitats) the plants were harvested at full flowering and then dried in a ventilated room without access to sunlight. The extracts were made by pouring $100 \mathrm{ml}$ water over $50 \mathrm{~g}$ of ground dried herbs for 24 hours (Wawrzyniak 1996) and filtered by using muslin. The plants were sprayed weekly in the evenings $(7,13,19,26$ of June, 5, 12, 18, 24, 31 of July, 12, 17 of August 2007 and 3, 9, 17, 24 of June, 7, 14, 21, 28 of July, 4, 11, 22 of August 2008). Cabbage that was not sprayed constituted the control. Five plants from each plot were inspected every week (1-2 days after spraying) and winged and wingless forms of the cabbage aphid (Brevicoryne brassicae L.), flea beetles (Phyllotreta sp.) and eggs and larvae of the butterflies (Pieris rapae L., P. brassicae L., Mamestra brassicae L.) and larvae and pupae of the diamondback moth DBM (Plutella xylostella L.) were counted. The Duncan multiple test $(p=0.05)$ was used for the statistical analysis of the results.

\section{RESULTS AND DISCUSSION}

Characteristic plant odours (volatile chemicals) are credited with the main role of guiding phytophagous

Table 1. Comparison of the occurrence of some pests on cabbage plants that were untreated and treated with plant extracts (2007-2008)

\begin{tabular}{|c|c|c|c|}
\hline Species of pest & A & $\mathrm{B}$ & $\mathrm{C}$ \\
\hline & \multicolumn{3}{|c|}{2007} \\
\hline \multicolumn{4}{|l|}{ Brevicoryne brassicae L. } \\
\hline Mean number of winged forms per plant & $17.76 \mathrm{c}^{*}$ & $7.87 \mathrm{a}$ & $14.52 \mathrm{~b}$ \\
\hline Mean number of aphids per plant & $56.10 \mathrm{c}$ & $22.68 \mathrm{a}$ & $36.75 \mathrm{~b}$ \\
\hline \multicolumn{4}{|c|}{ Mean number per 5 plants } \\
\hline $\begin{array}{l}\text { Phyllotreta } \mathrm{sp.} \\
\text { Beetles }\end{array}$ & $10.58 \mathrm{~b}$ & $3.17 \mathrm{a}$ & $8.31 \mathrm{~b}$ \\
\hline $\begin{array}{l}\text { Plutella xylostella L. } \\
\text { Larvae }\end{array}$ & $6.40 \mathrm{~b}$ & $3.10 \mathrm{a}$ & $6.56 \mathrm{~b}$ \\
\hline $\begin{array}{l}\text { Pieris rapae } \mathrm{L} . \\
\text { Eggs }\end{array}$ & $3.44 \mathrm{c}$ & $1.04 \mathrm{a}$ & $2.52 \mathrm{~b}$ \\
\hline \multicolumn{4}{|c|}{2008} \\
\hline Brevicoryne brassicae L. & & & \\
\hline Mean number of winged forms per plant & $4.00 \mathrm{~b}$ & $0.20 \mathrm{a}$ & $3.00 \mathrm{~b}$ \\
\hline Mean number of aphids per plant & $10.42 \mathrm{~b}$ & $3.10 \mathrm{a}$ & $6.90 \mathrm{~b}$ \\
\hline \multicolumn{4}{|c|}{ Mean number per 5 plants } \\
\hline $\begin{array}{l}\text { Phyllotreta } \text { sp. } \\
\text { Beetles }\end{array}$ & $8.52 \mathrm{c}$ & $2.12 \mathrm{a}$ & $4.10 \mathrm{~b}$ \\
\hline $\begin{array}{l}\text { Plutella xylostella L. } \\
\text { Larvae }\end{array}$ & $5.60 \mathrm{~b}$ & $1.92 \mathrm{a}$ & $5.67 \mathrm{~b}$ \\
\hline $\begin{array}{l}\text { Pieris rapae } \mathrm{L} . \\
\text { Eggs }\end{array}$ & $2.43 \mathrm{c}$ & $0.89 \mathrm{a}$ & $1.73 \mathrm{~b}$ \\
\hline $\begin{array}{l}\text { Pieris brassicae L. } \\
\text { Egg clusters } \\
\text { Eggs }\end{array}$ & $\begin{array}{l}0.10 \\
2.10 \\
\end{array}$ & - & - \\
\hline $\begin{array}{l}\text { Mamestra brassicae L. } \\
\text { Egg clusters } \\
\text { Eggs }\end{array}$ & $\begin{array}{l}0.06 \\
1.70\end{array}$ & - & - \\
\hline
\end{tabular}

*Means followed by the same letter are not significantly different $(\mathrm{p}=0.05)$

A - control - untreated cabbage

B - cabbage treated with water extract from pot marigold (Calendula officinalis L.)

$\mathrm{C}$ - cabbage treated with water extract from cypress spurge (Euphorbia cyparissias L.) 
insects to their host plants. In the process of host plant finding, glucosinolates are important phagostimulants for cabbage pests, present in all brassica plants (Ostroumow 1992, van Loon et al. 1992, Gabryś 1999, Pivnick et al. 1999).

Foraging phytophagous insect adults are attracted by host plant volatiles and supposedly repelled by volatiles from non-host plants. In the behavioural control of pest insects, chemicals derived from nonhost plants applied to crops are expected to repel searching adults and thereby reduce egg laying. The spraying of cabbage with the extracts of plants which were not host plants may mask their proper scent, especially if these plants contain as strong a scent as pot marigold. During both years of research, both kinds of water extracts had an effect on the occurrence of pests feeding on the cabbage. Although the cypress spurge extract contains cyanogenous compounds (Blaim 1965) and contained 0.5\% alkaloids in the period of inflorescence spurge (Mowszowicz 1982), pot marigold extract proved to control cabbage pests better. The flowers of Calendula officinalis contain flavonol glycosides, triterpene oligoglycosides, oleanane-type triterpene glycosides, saponins, and a sesquiterpene glucoside (Yoskihawa et al. 2001, Ukiya et al. 2006).

On plants that were treated with extracts, the number of cabbage aphid (Brevicoryne brassicae L.) was fewer as compared to the control variant. Significant differences were seen both in the number of winged aphids settling on plants and in the number of aphids on plants during the entire season (Tab. 1). In 2007, during the period of the most numerous occurrence of aphids on the unsprayed plants, their number was almost twice as high as on the plants sprayed with spurge extract and almost three times as high as on the plants sprayed with marigold extracts (Fig. 1). Many
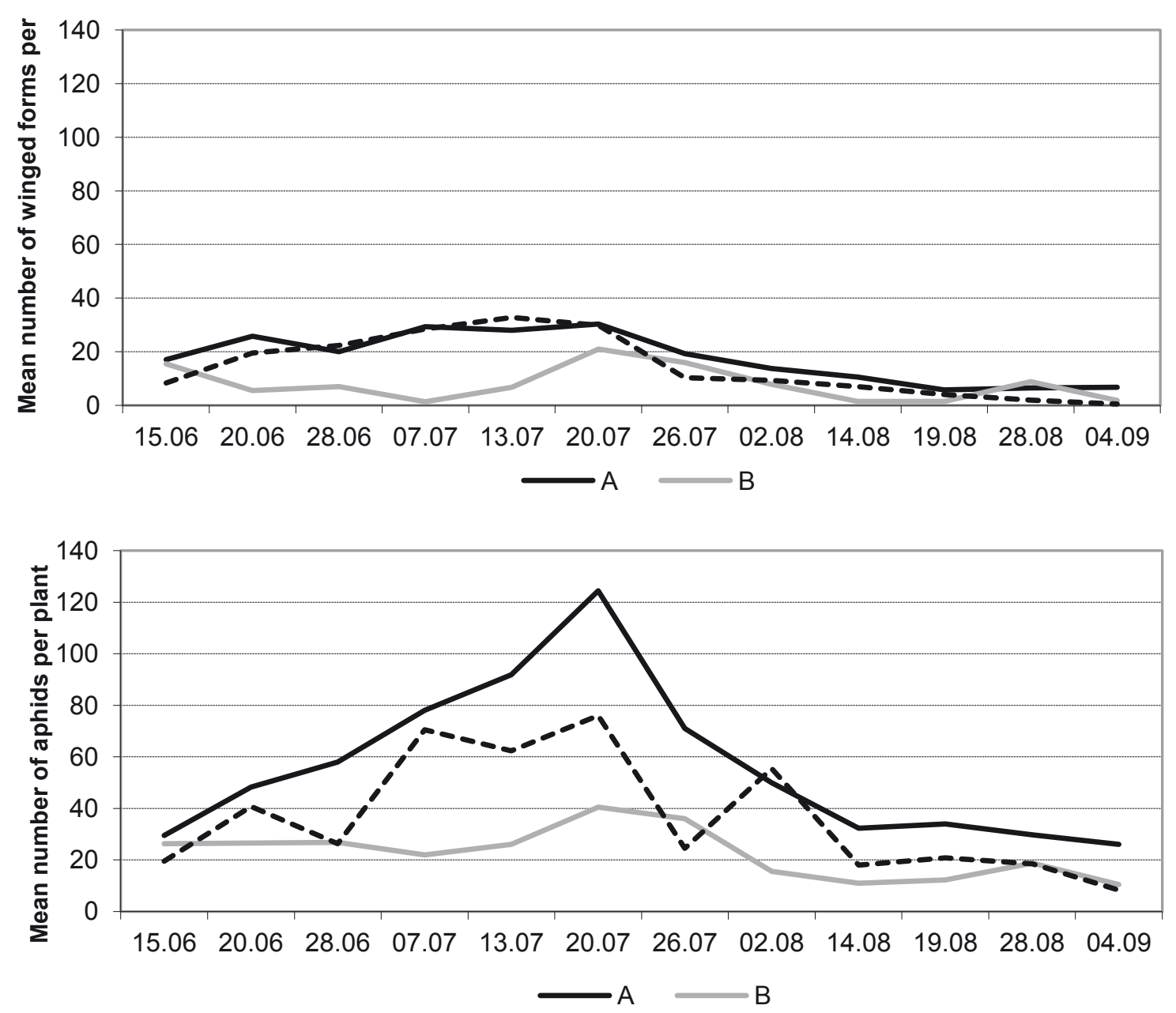

Figure 1. Population dynamics of cabbage aphid (Brevicoryne brassicae L.) on cabbage plants that were untreated and treated with plant extracts in 2007

A - control - untreated cabbage

$\mathrm{B}$ - cabbage treated with water extract from pot marigold (Calendula officinalis L.)

$\mathrm{C}$ - cabbage treated with water extract from cypress spurge (Euphorbia cyparissias L.) 

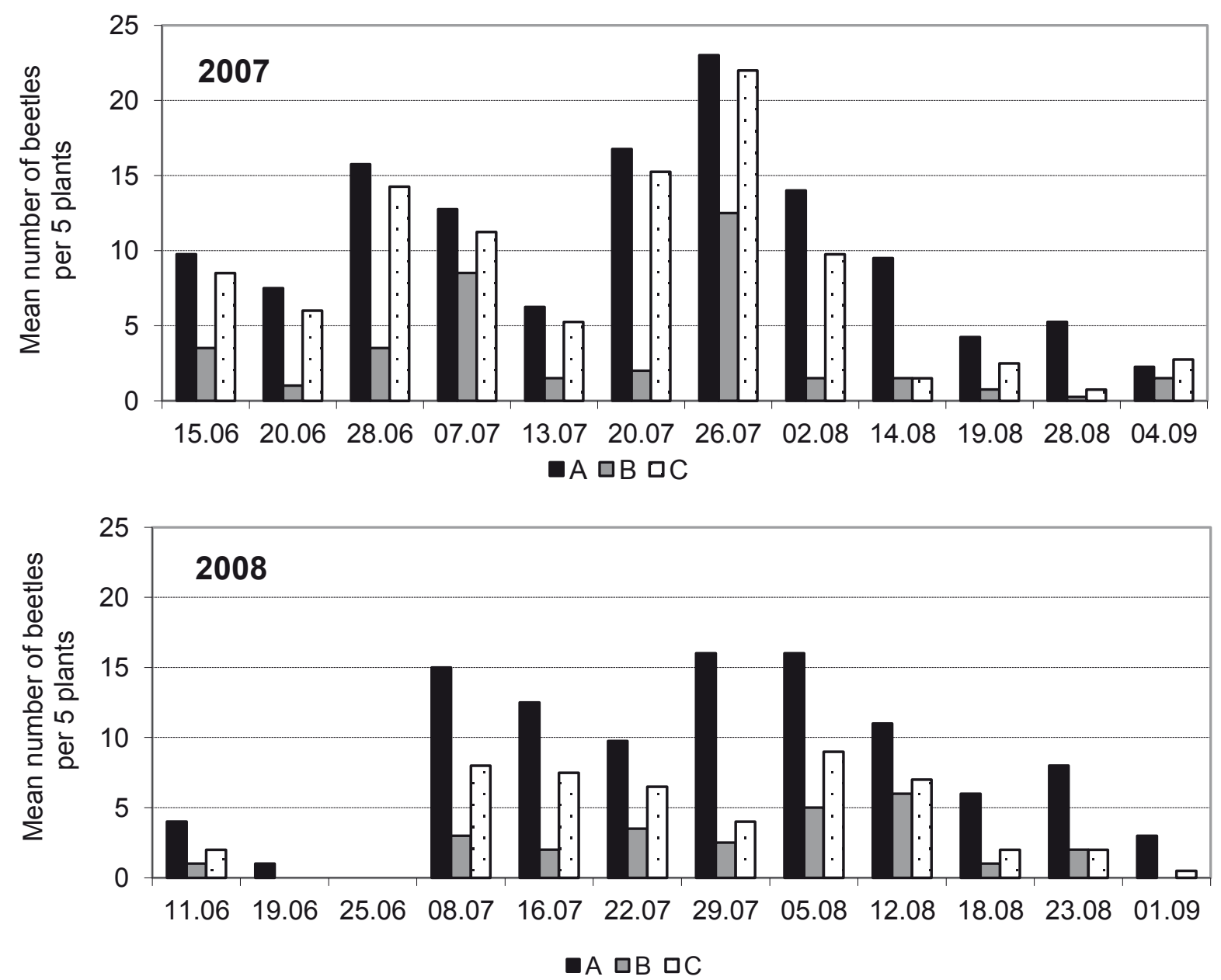

Figure 2. The population dynamics of flea beetles (Phyllotreta sp.) on cabbage plants that were untreated and treated with plant extracts

A - control - untreated cabbage

$\mathrm{B}$ - cabbage treated with water extract from pot marigold (Calendula officinalis L.)

$\mathrm{C}$ - cabbage treated with water extract from cypress spurge (Euphorbia cyparissias L.)

researchers have observed antifeedant activity of plant extracts in relation to aphids (Endersby and Morgan 1991). Plant extracts may also cause the mortality of aphids that are already on the plants (Achremowicz 1995, Achremowicz and Cież 1998). Księżak et al. (2008) recorded a decrease in the number of black bean aphids on faba bean (Vicia faba minor) using saponin from alpha-alpha. Alpha-alpha saponin was also used by Puszkar et al. (1994) to limit the number of damson-hop aphids on hops. To limit the number of aphids, Barczak and Gulewicz (1998) used lupine extracts. According to many researchers, the application of plant extracts did not affect the performance of insect pests' natural enemies, but Jankowska and Wilk (2009) noted that extracts lowered the number of parasitised aphids (mummies) on plant, though the highest level of parasitation was recorded in aphid colonies feeding on plants sprayed with pot marigold extract. Also, other researchers observed a negative impact of plant extracts on parasitoids (Barczak 1994, Wyrostkiewicz et al. 1996).

Two flea beetle species were noted during the study: Phyllotreta nemorum L. and Phyllotreta atra Fabr. In all of the years of observation and in every combination, the dominant flea beetle species was $P$. nemorum. The number of beetles was lower on sprayed cabbage as compared with unsprayed cabbage (Fig. 2), but a significant difference in both years occurred only in the case of the marigold extract (Tab. 1). According to Tahvanainen and Root (1972), the highly odorous ragweed (Ambrosia artemisifolia) could be used to repel the flea beetle P. cruciferae from a collard crop.

In the case of the diamondback moth Plutella xylostella L., only marigold extract had a positive impact on reducing its number (Fig. 3). Diamondback moth larvae numbers were even slightly higher 

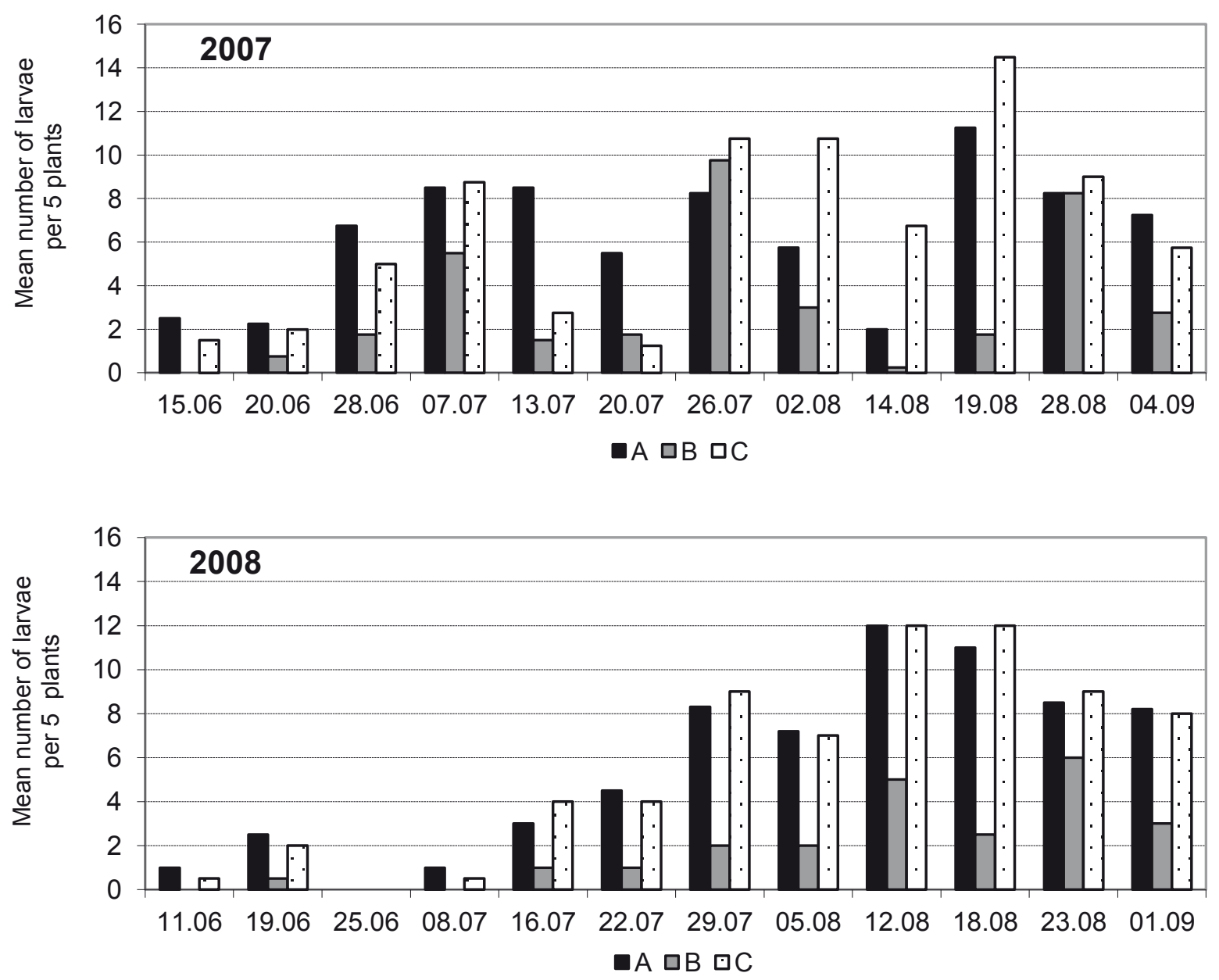

Figure 3. The population dynamics of diamondback moth (Plutella xylostella L.) on cabbage plants that were untreated and treated with plant extracts

A - control - untreated cabbage

$\mathrm{B}$ - cabbage treated with water extract from pot marigold (Calendula officinalis L.)

$\mathrm{C}$ - cabbage treated with water extract from cypress spurge (Euphorbia cyparissias L.)

on plants treated with cypress spurge extract than on control plots where plants were not sprayed (Tab. 1). In an experiment by Shu-Sheng et al. (2005), ovipositing DBM females were repelled by an extract of dried Chrysanthemum morifolium leaves, a non-host plant of DBM, but experienced females were not repelled. Charleston et al. (2005) noted that in laboratory and glasshouse trials significantly fewer eggs were oviposited on plants that had been treated with syringa (Melia azaderach) extracts. Dadang and Ohsawa (2001) noted that two plant extracts, from Alpinia galanga and Gomphrena globosa, significantly reduced $P$. xylostella larval density and proved more effective than Decis 72.5 EC.

The botanical insecticides had less of an effect on the oviposition behaviour of small white butterfly Pieris rapae L. Significantly fewer eggs were oviposited on the plants that had been treated with plant extracts (Fig. 4). Pot marigold extract proved to be the most effective in this respect (Tab. 1). Extracts significantly decreased the oviposition activity of large white butterfly Pieris brassicae L. and cabbage moth Mamestra brassicae L. Egg clusters were observed only in the control (Tab. 1). Wawrzyniak (1996) recorded pot marigold extract antifeedant activity in relation to $P$. brassicae caterpillars in laboratory conditions. In field conditions, the spraying of plants protected them from eggs being laid by females of this butterfly species (Wawrzyniak 1996). A similar effect was achieved by spraying plants with French marigold (Tagetes patula) extract (Jankowska 2008). Also, the introduction of pot marigold and French marigold as intercropping plants for cabbage caused a significant increase in the number of aphids settling plants (Jankowska 2007) and other phytophags that feed on cabbage (Jankowska et al. 2009). 

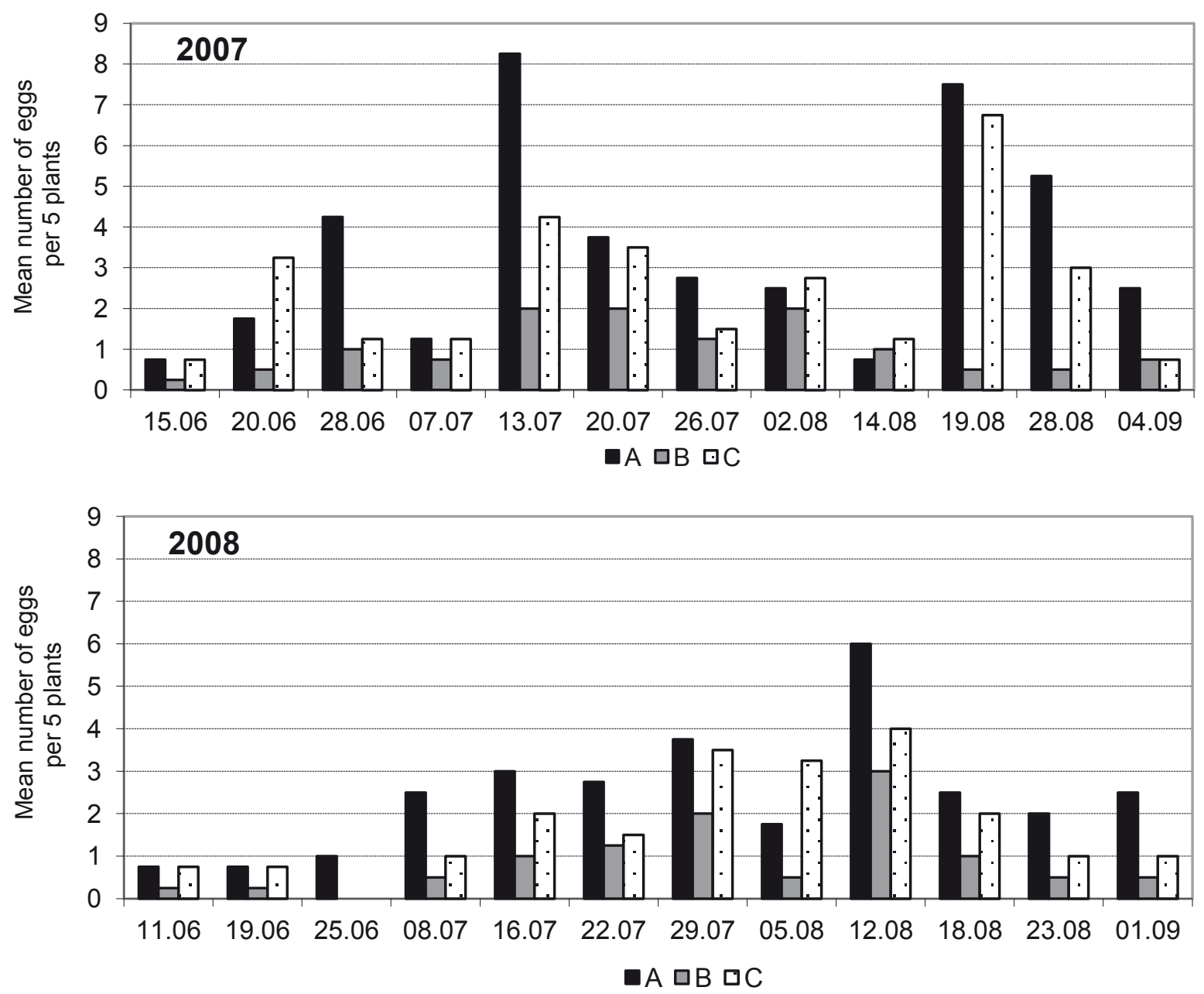

Figure 4. Egg-laying dynamics of small white butterfly (Pieris rapae L.) on cabbage plants that were untreated and treated with plant extracts

A - control - untreated cabbage

$\mathrm{B}$ - cabbage treated with water extract from pot marigold (Calendula officinalis L.)

$\mathrm{C}$ - cabbage treated with water extract from cypress spurge (Euphorbia cyparissias L.)

Oviposition and feeding deterrent properties are important factors in pest control, and the results of this study indicate that Calendula botanical insecticides have the potential to be incorporated into control programmes for cabbage pests. Dadang et al. (2008) noted that the formulations should contain two or more plant extracts to make the formulation more effective. Another important matter in the application of botanical insecticide formulations should be their compatibility with other integrated pest management strategies.

\section{CONCLUSIONS}

1. Water extracts from pot marigold and cypress spurge lowered the number of cabbage aphids, Phyllotreta beetles and P. rapae eggs on plants. Calendula officinalis extract proved to have a better effect.
2. In the case of the diamondback moth Plutella xylostella L., only marigold extract had a positive impact on reducing its number.

\section{REFERENCES}

Achremowicz J., 1995. Badania nowych aficydów pochodzenia roślinnego. Pestycydy 4: 27-36.

Achremowicz J., Cież W., 1998. Doświadczenia nad skutecznością działania wyciagów $\mathrm{z}$ roślin stosowanych jako aficydy. Zesz. Probl. Post. Nauk Rol. 353: 53-66.

BARCZAK T., 1994. Wpływ wyciagów z roślin z rodziny rdestowatych na mszycę burakową (Apis fabae Scop.) i jej parazytoidy. Zesz. Probl. Post. Nauk Roln. 414: 245-252.

Barczak T, Gulewicz K., 1998. Evaluation of the effect of lupin-nicotine preparation on black bean aphid (Aphis fabae Scop.) and its parasitoids (Hymenoptera: Parasitica). Pol. J. Entomol. 67: 155-163. 
Blaim K., 1965. Swoiste substancje roślin uprawnych. PWRiL, Warszawa: 308.

Burgiet Z., 2005. Czy preparaty roślinne zastapią syntetyczne pestycydy? In: Ochrona środowiska naturalnego w XXI - nowe wyzwania i zagrożenia. Fundacja na wspierania badań naukowych W.O, A.R. w Krakowie: 116-123.

Charleston D.S., Kfir R., Vet L.E.M., Dicke M., 2005. Behavioural responsem of diamondback moth Plutella xylostella (Lepidoptera: Plutellidae) to extracts derived from Melia azedarach and Azadirachta indica. Bull. Entomol. Res. 95(5): 457-465.

DADANG L., OHSAWA K., 2001. Efficacy of plant extracts for reducing larval population of the diamondback moth, Plutella xylostella L. (Lepidoptera: Yponomeutidae) and cabbage webworm, Crocidolomia binotalis Zeller (Lepidoptera: Pyralidae) and evaluation of cabbage damage. Appl. Entomol. Zool. 36(1): 143-149.

Dadang L., Andriani, Ohsawa K., 2008. Compatibility of Annonaceae and Meliaceae plant extract mixtures in causing mortality effect against the cabbage head caterpillar, Crocidolomia pavonana (F.) (Lepidoptera: Pyralidae) larvae. J. ISSAAS 13(3): $1-16$.

Endersby N.M, Morgan W.C., 1991. Alternatives to synthetic chemical insecticides for use in crucifer crops. Biol. Agric. Hortic. 8: 33-52.

Gabryś B., 1999. Siemiozwiązki w biologii i ekologii mszycy kapuścianej Brevicoryne brassicae L. Zesz. Nauk. AR we Wrocławiu, rozp. hab. Nr 356: 84 pp.

JANKOWSKA B., 2005. The comparison of the occurrence of the diamondback moth Plutella xylostella L. (Lepidoptera, Plutellidae) on the different cabbage vegetables. Veg. Crops Res. Bull. 62: 153-163.

JANKOWSKA B,. 2006. The occurrence of some lepidoptera pests on different cabbage vegetables. J. Plant Protection Res. 46(2): 181-190.

JANKOWSKA B., 2007. Impact of intercropping white cabbage with Pot Marigold (Calendula officinalis L.) and French Marigold (Tagetes patula nana) on the occurrence of cabbage aphid (Brevicoryne brassicae L.), its parasitoid Diaeretiella rapae M'Intosh and predatory Syrphidae. Aphids and Other Hemipterous Insects 13: 199-209.

JANKOWSKA B., 2008. Wpływ wodnego wyciagu $\mathrm{z}$ aksamitki (Tagetes patula nana) na występowanie szkodliwej entomofauny na kapuście białej. Prog. Plant Protection / Post. Ochr. Roślin 48(2): 724-729.

Jankowska B., Poniedzialek M., Jędrszczyk E., 2009. Effect of intercropping white cabbage with French Marigold (Tagetes patula nana) and Pot Marigold (Calendula officinalis L.) on the plants colonization by herbivorous pest insects. Folia Hort. 21(1): 95-103.

JANKOWSKA B., WieCH K., 2004. The comparison of the occurrence of the cabbage aphid (Brevicoryne brassicae L.) on the cabbage vegetables. Veg. Crops Res. Bull. 60: 71-80.

JANKOWSKA B., WiLK A., 2009. The impact of plant water extracts from Calendula officinalis L. and Euphorbia cyparissias L. on the occurrence of Brevicoryne brassicae Linneaus, 1758 /Hemiptera, Aphidoidea/ and its parasitoid Diaeretiella rapae (M'Intosh, 1855) /Hymenoptera, Ichneumonoidea/. Aphids and Other Hemipterous Insects 15: 195-204.

KsıĘżAK J., BıAŁy Z., Кот I., 2008. Ocena możliwości wykorzystania saponin lucerny (Medicago ssp.) do zwalczania mszycy burakowej w uprawie bobiku. Prog. Plant Protection / Post. Ochr. Roślin 48(3): 903-907.

Loon J.J. van, BlaAkmer A., Griepink F.C., Beek T.A. van, Schoonhoven L.M., Groot A., 1992. Leaf surface compounds from Brassica oleracea (Cruciferae) includes oviposition by Pieris brassicae (Lepidoptera: Pieridae). Chemoecology 3: 39-44.

Mowszowicz J., 1982. Przewodnik do oznaczania krajowych roślin trujących i szkodliwych. PWRiL, Warszawa: 479.

NAwrot J., 1984. Produkty naturalne w ochronie roślin. Pestycydy 3(4): 1-31.

Ostroumow S.A., 1992. Wprowadzenie do ekologii biochemicznej. PWN, Warszawa: 205.

Pivnick K.A., Jarvis B.J., Slater G.P., Gillot C., UNDERHILl E.W., 1999. Attraction of the diamondback moth (Lepidoptera, Plutellidae) to voliaties of oriental mustard: The influence of age, sex and prior exposure to mates and host-plants. Environ. Entomol. 19: 704-709.

Puszkar L., JastrzębSki A., Jurysta M., BiaŁy Z., 1994. Saponiny lucerny jako szansa w integrowanej ochronie chmielu. 34 Sesja IOR (2): 255-259.

Shu-Sheng L., Yue-Hong L., Yin-Guan L. Zalucki M.P., 2005. Experience induced preference for oviposition repellents derived from a non-host plant by a specialist herbivore. Ecol. Lett. 8(7): 722-729.

SzwEJDA J., 2004. Przegląd szkodników i ich wrogów naturalnych aktualnie występujących na warzywach kapustowatych w Polsce. Now. Warz. 39: 97-102.

Tahvanainen J.O., Root R.B., 1972. The influence of vegetational diversity on the population ecology of a specialized herbivore Phyllotreta cruciferae (Coleoptera: Chrysomelidae). Oecologia 10: 321-346.

Ukiya M., Akinisa T., Yasukawa K., 2006. Antiinflammatory, anti-tumor-promoting, and cytotoxic activities of constituents of pot marigold (Calendula officinalis) flowers. J. Nat. Prod. 69: 1692-1696.

WAWRZYNIAK M., 1996. Ocena działania wybranych ekstraktów roślinnych na bielinka kapustnika. ATR w Bydgoszczy, rozp. hab. Nr 70: 61 pp.

Wyrostkiewicz K., WaWrzyNiAK M., BARCZAK T., Aniszewski T., Gulewicz K., 1996. An evidence for insecticide activity of some preparations from alkaloid-rich lupin seeds on colorado potato beetle (Leptinotarsa decemlineata Say), larvae of the large 
white butterfly (Pieris brassicae L.), black bean aphid (Aphis fabae Scop.) and on their parasitoids (Hymenoptera, Parasitica) populations. Bull. Pol. Acad. Sci. Biol. Sci. 44(1-2): 29-39.

YoshiKawa M., Murakami T., Kishi A., 2001. Medicinal flowers. III. Marigold.(1): hypoglycemic, gastric emptying inhibitory, and gastroprotective principles and new oleanane-type triterpene oligolycosides, calendasaponins A, B, C, and D, from Egyptian Calendula officinalis. Chem. Pharm. Bull. 49: 863-870.

\section{WPEYW WODNYCH WYCIĄGÓW Z}

NAGIETKA (CALENDULA OFFICINALIS L.)

I WILCZOMLECZA SOSNKI (EUPHORBIA

CYPARISSIAS L.) NA WYSTĘPOWANIE

SZKODLIWEJ ENTOMOFAUNY NA KAPUŚCIE BIAŁEJ

Streszczenie: W latach 2007-2008 badano wpływ wodnych wyciagów z nagietka lekarskiego (Calendula officinalis L.) i wilczomlecza sosnki (Euphorbia cyparissias L.) na występowanie niektórych szkodników na kapuście białej. $\mathrm{Na}$ roślinach opryskiwanych wyciagami obserwowano istotnie mniej mszycy kapuścianej Brevicoryne brassicae L. W okresie najliczniejszego występowania na roślinach opryskiwanych wyciagiem z wilczomlecza było jej dwukrotnie mniej, a na roślinach opryskiwanych wyciagiem $\mathrm{z}$ nagietka trzykrotnie mniej niż na poletkach kontrolnych. Opryskiwanie roślin miało wpływ także na zmniejszenie na roślinach liczebności pchełek (pchełki smużkowanej Phyllotreta nemorum L. i pchełki czarnej $P$. atra Fabr.), oraz jaj bielinka rzepnika Pieris rapae L. Lepszy pod tym względem okazał się wyciąg z nagietka. Nieliczne złoża jaj bielinka kapustnika $P$. brassicae L. i piętnówki kapustnicy Mamestra brassicae L. obserwowano tylko w 2008, tylko na poletkach kontrolnych. W przypadku tantnisia krzyżowiaczka Plutella xylostella L. tylko wyciag znagietka miał pozytywny wpływ na obniżenie jego liczebności. Na roślinach opryskiwanych wyciagiem z wilczomlecza gąsienic i poczwarek tantnisia było nawet nieco więcej niż na poletkach kontrolnych, gdzie rośliny nie były opryskiwane.

Received December 6, 2010; accepted September 22, 2011 